\title{
The Development Of Election Smart House As A Tool of Political Education Based On Local Wisdom
}

\author{
${ }^{1}$ AL RAFNI, ${ }^{2}$ SURYANEF SURYANEF \\ 1, 2 Universitas Negeri Padang, Jalan Prof. Dr. HAMKA, Indonesia. \\ email : 12alrafni@fis.unp.ac.id, 2suryanef@fis.unp.ac.id
}

\begin{abstract}
Election Smart house that established by the General Election Commission in every province is the innovative effort in providing the facility for political education in society. The problem is RPP has not been used optimally by users and still needs to be institutionalized as a tool of political education based on local wisdom. This paper aims to elaborate on the forms of political education activities, especially voter education contained in the RPP, even how the model for the development of RPP as a tool of political education based on local wisdom. The research approach uses a more intensive qualitative approach through focus group discussions/ FGDs and in-depth interviews. While to build the model, Research and Development ( $\& D$ ) are used. The results of the study show that the political education services contained in the lesson plan need to be developed by standardizing services and supporting facilities that can be a model for political education facilities for the community based on local wisdom.
\end{abstract}

Keywords: election smart house, political education, local wisdom

\section{Introduction}

One of the things that influence the level of community literacy towards politics and at the same time determines participation in voting is how the community be educated to be smart voters. Elections that have a certain quality require smart and critical voters. This will be fulfilled if the voters are political educated. Therefore, an intensive, continuous and programmed political education process is needed to improve voter quality and the quality of democratic life. So far, political education for the community has not been arranged systematically and there is no clear program that has been carried out either by the regional government, political parties, including the General Election Commission (KPU) (Rafni and Suryanef, 2016).

The existence of election smart homes (herein after referred to as RPP) as one of the national priority programs rolled out by the KPU since 2016 has become an important to answer the needs of voters, the general public and the tools to educate democratic materials and especially electoral issues. The RPP program starts with project pilots in the provincial KPU and $18 \mathrm{KPU}$ from district/city. In 2016 it was continued to 10 provincial KPUs and it is expected that in 2018 all provinces and districts/cities around Indonesia will have RPPs. Thus, there will be 327 RPPs in Indonesia.

When it observed at the guidelines for implementing the RPP, it aims to increase voter participation in elections in both quality and quantity. Improving the quality of democracy and awareness of the importance of democratic life are the focal points for the implementation of this RPP program.

RPP that is established in all provinces, districts/cities actually becomes a tool of political education for the community based on local wisdom if it can be managed and utilized optimally. Some findings from the RPP project pilot evaluation according to Sigit Joyowardono (Head of the Indonesian Commission's Technical and Public Relations) at the RPP Rakornas on 19-21 May 2016 in Bali, it is need to be increased the voter education activities as the substance of democratic education in RPP and also the resources that manage RPP. Besides that,

Received: 2018-10-09, Revisied: 2019-01-29, Accepted: 2019-06-01

Print ISSN: 0215-8175; Online ISSN: 2303-2499. DOI: http://dx.doi.org/10.29313/mimbar.v35i1.4122

Accredited $\mathbf{S 2}$ based on the decree No.10/E/KPT/2019 until 2024. Indexed by DOAJ, Sinta, Garuda, Crossreff, Dimensions 
it was also revealed that there was no achievement in the level of the target at the community participation in regional head elections in 2015 (the average participation rate was only $69.09 \%$ ), as well as facilities and infrastructure that were not maximized in most of the pilot projects. Other findings also reveal the importance of political education programs that are planned, measurable, sustainable and participatory.

Learning from cases that occurred in several regions as revealed by the statement of the KPU Chairman from Banten Agus Supriyana, that is RPP can be the center of studies and research as well as information about elections and democracy. The entire community can learn about the history of democracy in Banten (pilarbanten.banten. com.indexphp.item), while the Chairperson of the KPU. NTT Province Maryanti Luturmas Adoe stated that RPP in Kupang City KPU was built with the aim of educating the public in conducting activities related to regional head elections (pilkada) and electoral elections, including pre-voters such as elementary students who were invited to launch KPP because in the learning material they have material about democracy and local elections (Learning democracy from RPP; timorexpress.com.fajar.co.id 2017/04-08). This is in accordance with the opinion of Saha in Rafni and Suryanef (2018) that is at an early age children in the America, Britain and Australia began to get the foundation for their political learning, for further Peter revealed his research in three countries, those are America, Denmark and Sweden about how the role and influence of political information on choosing community participation, especially in the group of children pre-selector(Dinesen et al ., 2016)

Every province or district/city that establishes RPP is expected to be able to characterize the RPP with regional special characters or using local wisdom in educating the society. Educational efforts integrated the values of local wisdom prioritize the program above to raise awareness of their own cultural values and further develop these cultural values in an innovative and creative way.

According to Radmila in Wirdanengsih (2018), local wisdom is local ideas that are of good value, have been maintained throughout the period, and are followed by members of the community. The values of local wisdom develop in people's lives and are very well used as a means of political learning; the community easily understands especially the content.

Local wisdom according to Bima Widjajaputra can be seen through (1) local norms developed from generation to generation; (2) rituals and traditions of the community and the meaning behind the tradition; (3) folk songs, the proverbial adage, folklore that has certain messages understood by the community; (4) information, data and knowledge obtained from the dialogue process, interviews with elders and community leaders; (5) scriptural texts that are believed by the community; (6) the ways the community fulfills its needs; (7) devices of technological tools used to meet certain needs; and (8) environmental conditions and how they adapt to the environment in order to fulfill their needs (Wirdanengsih, 2018).

One example of local wisdom-based political learning is the program indigenous electoral participation which is a continuous collaboration of the KPU with local communities to achieve a better democratic life (Ahmed, 2016) (Setiawaty, 2014). This article aims to: (1) describe how the form of political education services contained in the RPP; and (2) reconstructing the model of RPP development as a tool of political wisdom based on local wisdom.

\section{Research Methodology}

This is development research (Research and Development $=R \& D$ ), using the ADDIE model. The first step is to identify the forms of political education activities (services) contained in the RPP and how to manage them so that they can facilitate the implementation of sustainable political education. Then development research is carried out with the ADDIE method with the following steps: (1) analysis ; (2) design ; (3) development; (4) implementation; and (5) evaluation in expressing and analyzing the suitable model to reconstruct the model of RPP development as a tools of sustainable political education based on local wisdom.

The instrument used to collect data is the interview guide, focus group discussion (FGD). The FGD was conducted in gathering information about the forms and mechanisms of service in the RPP to be more optimal. Besides that, data collection also uses to sets, and model validation instruments by experts consisting of KPU Commissioners, Technical Section of KPU Socialization, political scientists, political education scientists, 
and educational scientists themselves. The development method is considered comprehensive because at each stage it can be evaluated for improving the model (Morrison, Ross and Kalman, 2019). While the informants consisted of the West Sumatra Provincial KPU Commissioner and KPU from Bukittinggi, the technical and community relations section along with staff who were responsible for managing the RPP.

\section{Results and Discussion}

\section{Form of Political Education Services at Election Smart Houses.}

The services of political education activities for the people contained in the RPP can be explained using space in the RPP. The research findings show that from the four available spaces, namely the audiovisual room, showroom, discussion room, and simulation room, the audiovisual room is often visited. Audiovisual space is used for screening films related to national elections or local elections. Making local films with animated forms can be used as a tool of political learning. This is as expressed by Harrison Iii and Hummell (2010) that the tendency of students to prefer animated films. Animated films are able to enrich students' experiences and competencies in a variety of material presentations. The materials presented through film/video shows have an impact on student motivation in participating in elections or democratic life. The research findings show that elementary school students as pre-voters are more enthusiastic in learning Civics Education (PPKn) about elections and state institutions through RPP both in the audio visual space, as well as showrooms and

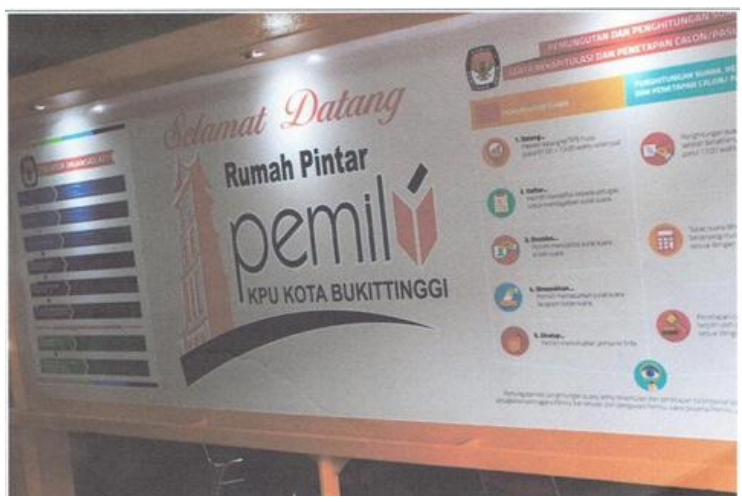

Figure 1:

Information submitted from one of the headers in the Bukittinggi City Election Commission RPP

(Source: Report of the Smart House Election Commission of the City of Bukittinggi (2018).) discussion rooms. This condition is supported by the availability of learning tools in the form of display that includes various aspects of the election that are informative and interesting. One of them as shown in figure 1. Here is illustrated the process and stages of the election. While in figure 2 shows how enthusiastic the elementary school students are in learning things related to election problems and state institutions. Critically they questioned the role of the KPU as the organizer of the election and its relation to filling in positions in state institutions.

Next, the research findings also revealed that there were no films produced specifically in accordance with local election content. Meanwhile showroom/display props / electoral contains information about the impression of how the essence of electoral itself regarding how the election management bodies formed, the electoral system is used, why the election is important, and impressions about the stages of the election. Besides that, there are also models/dioramas about voting procedures at polling stations (TPS). The diorama models are made through robotic techniques so that pre-voters and beginner voters can experience the learning more. How is voting done? Political education services in this room are very dependent on the form of media provided. Political information about elections and democracy if it is effective, the RPP also makes local media that attracts visitors such as the history of elections in the city of Padang, and the electoral sayings that can be understood by local people. Likewise in the simulation room. Not only presents the election process at polling stations but the simulation is equipped with local values in the electoral process itself such a badun sanaks elections in Padang or West Sumatra

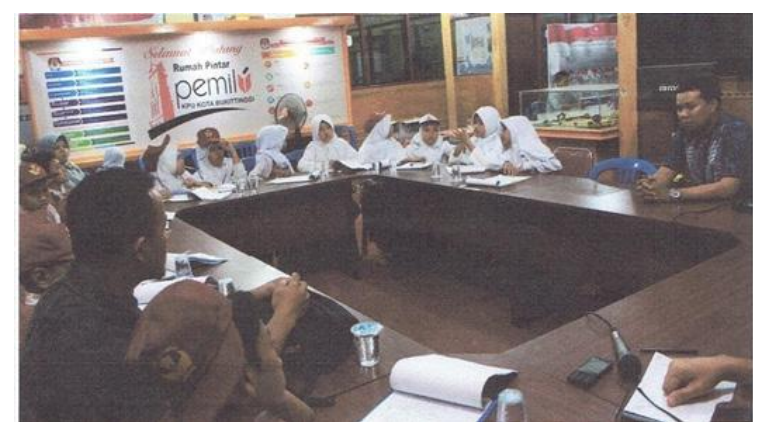

Figure 2:The atmosphere of Visiting SD IT Desiring by Solok Regency to RPP of KPU in City of Bukittinggi

(Source: Report of Smart House Election of Election Commission of City of Bukittinggi (2018). 
Province in particular.

Then, the discussion room becomes a room that has the opportunity to carry out deeper political education. This room can be used for a variety of political learning in the form of attempts to discuss common interests. Unfortunately, the use of space for activities that involve many people in political learning has not been optimal. It was proven that the intensity of visits and their utilization was still low. Another issue that could be addressed is the unavailability of a special counselor to assist visitors. The influence of the information presented will have an effect on people's behavior towards political phenomena. Fowler and Margolis (2014) in his research explained that political information influences citizens' attitudes towards parties in the United States. When citizens who have lack information receive public information, they automatically replace their political preferences. Especially in the era of the Industrial Revolution 4.0, the role of information technology such as the procurement of web for political learning is very necessary in the RPP so that information is distributed interactively. Procurement of web for political learning is sometimes also used as the main means for the community. As explained in the study. As stated by Sánchez-Villar, Bigné, and Aldás-Manzano (2017) which proves that the procurement of the web, and many users of the blog can be a means for the community in the provision of criticism and feedback to the ruler. In the research of J. Sánchez-Villar et al took 39 web blogs as samples and blog users totaling 890 bloggers.

Besides guider, another form of service in the RPP is in the form of inviting schools through collaboration with the local education office. Schools that meet the invitation is still limited. In fact, through the facilities/ means of learning on the RPP will bring students to learn contextually. Students will understand the urgency of the election and how the government works for the benefit of all citizens. Political studied especially through the contextual information that will allow students to appreciate the workings of government and encourage them to trust, be positive, and participate in politics (Pacho, 2014).

\section{RPP Development Model as a Tool of Political Education Facility in society Based on Local Wisdom.}

To optimize the use of the RPP, the RPP should be developed through a needs analysis as a development model ADDIE (Analysis, Design, Development, Implementation and Evaluation). This is due to the political education process needs to be specially designed so that the end result can be internalized in each individual community. In the phase of analysis, the research findings show several things that need to be developed, those are: First, providing local content about electoral and democracy such as democracy in Minangkabau customs. How to choose leaders in the context of local wisdom or the importance of political communication based on local wisdom. Second, formulate and establish educational programs such as educational programs for pre-voters, educational programs for beginner voters, educational programs for the female voter segment, and programs for the general public. Third, formulate RPP management management that can facilitate the implementation of sustainable political education which consists of: (1) how information is managed and packaged properly so clearly the content and purpose;(2) how the management of related services extension and quality of service can be guaranteed;(3) how the development of the principle of learning from the planning, implementation, and evaluation of learning; and (4) how all existing resources in the form of output that has been produced can be produced well, smoothly and sustainably. Furthermore, the fourth is to establish an evaluation system for RPP development which includes evaluating the implementation and evaluation of RPP management.

After determining the needs analysis the second stage is carried out, that is the design phase. In this design phase the following are carried out: (1) constructing a model for the development of RPP as a tools of political education facility for society based on local wisdom; (2) compiling a guidebook for RPP management; (3) formulate books on political education materials and learning strategies; and (4) compile the RPP evaluation guidebook which involves evaluating the implementation of political education and evaluating its management.

The research findings also indicate that efforts are needed to make traditional games such as snake ladder elections, electoral puzzles used as learning models of local wisdom-based political education. Utilization of a game that has been a tradition from generation to generation, in the end, can support the formation of political literacy 
community.

Furthermore, the problem of the development of the RPP concerning human resources, the research findings indicate that training needs to be prepared for the guider in the existing RPP. While there are no special officers available to provide information services to visitors. The special officers in question function as facilitators of political education that need to be trained and prepared from the start. The training is basically an effort to obtain knowledge, skills, and attitudes that can be used to improve performance, at least three guides/facilitators are needed in the RPP.

The third stage is the development stage that is in the form of (1) constructing a model of RPP service development as a tools of political education facility for society based on local wisdom; (2) developing manuals for political education and learning material; and (3) developing the RPP evaluation guidebook concerning guidelines for evaluating the implementation of political education in the RPP and evaluating the management of RPP.

Based on the research findings, the construction of the RPP development model as a tool of sustainable political education based on local wisdom as seen in diagram 1.

Developing RPP as a tools of ongoing political education based on local wisdom in this case Minangkabau culture refers to traditional values that have long existed in community and state life such as egalitarian values, religious values, togetherness values, consensus values, and mutual cooperation values and there are still many values of Minangkabau local wisdom that can support knowledge, attitude, and behavior of the community in using their voting rights and involvement in elections. Based on the results of the Focus Group Discussion(FGD, Focus Group Discussions), the research findings show the importance of local wisdom values, for example in terms of the spirit and principles of democracy that have long developed in the Minangkabau ethnic community. The se values existed long before the arrival of European countries to Indonesia. This is evidenced through the traditional philosophy of the Minangkabau ethnic group that developed in accordance with the dynamics of the life of the nation and state. This spirit of democracy is reflected in the proverb of the Minangkabau custom, among others, kato mufakaik nan bakuaso(an agreement that is in power). Basilang kayu ditungku mako api bias iduik(crossing wood in the stove so that the fire can blaze).Bulek aia dek pambuluah, bulek kato dek mufakaik (round water because of vessels, round word because consensus). Ditinggikan sarantiang, didahulukan salangkah (at the only a branch, take just one step). Duduak samo randah, tagak samo tinggi(as low as sitting and as high as standing) (Wirdanengsih, 2018).

Kato mufakaik symbolizes the sincerity of the Minangkabau community to deliberate to reach consensus. The importance of deliberation for the Minangkabau community is due to the results of the deliberations above everything, as revealed in the sekalipuninggok nan mancakam, kuku nan tajamtakpaguno, walapunmamaciktampuakalam, katomufakaik nan bakuaso (though perched on a grip, useless sharp nails, despite holding the reins of nature, the consensus reached in power). While the saying basilang kayu dalam tungku mako api kaiduik (crossing wood in a stove so that the fire will blaze), this tools that every problem can be solved by crossing opinions in each meeting. Every issue discussed so that it can be solved (Nusyirwan, in Wirdanengsih, 2018).

Furthermore, because the election is a tool that associated with the selection of leaders who will sit in the legislative and executive institutions, the FGD forum also recommends that the RPP can accommodate Minangkabau traditional teachings in the concept of leadership. In Minangkabau custom philosophy a leader cannot play the role of king, sultan or emperor. He is only given a position a little higher than ordinary people, as reflected in the traditional expression ditinggikan sarantiang, didahulukan salangkah (raised a little bit, take precedence). The political consequences, if the leader is arbitrary or not aspirational, then the people or people's representative institutions may argue and even replace them with leaders who are considered better. Respect for the rights of others is also reflected in the expressions nan ketek dilindungi, nan tuo dihormati, nan samo gadang dipatenggangkan (the smaller ones are protected, the greater are respected, and are equally valued). The same is true with the principle that every work that is social in nature is always carried out together. This is revealed in the proverb barek samo dipikua, ringan samo dijinjiang (the same weight is carried, light is equally carried).

Meanwhile educational programs that must be included in the RPP are as follows: 


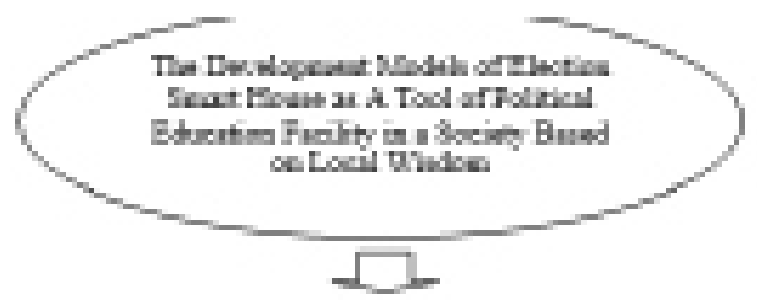

\section{MEFT AKHIST:}

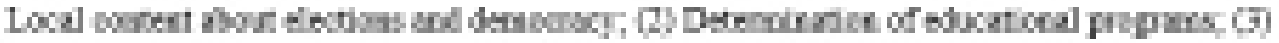

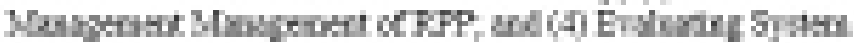

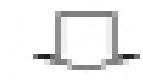

\section{IEALA:}

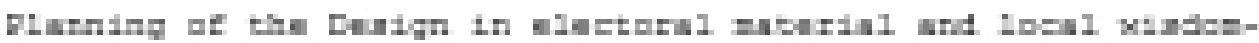

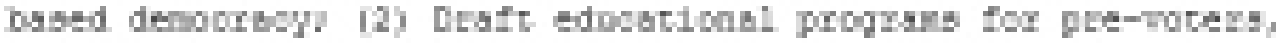

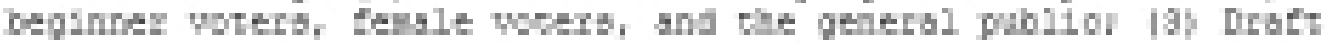

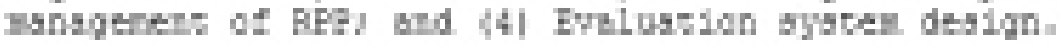
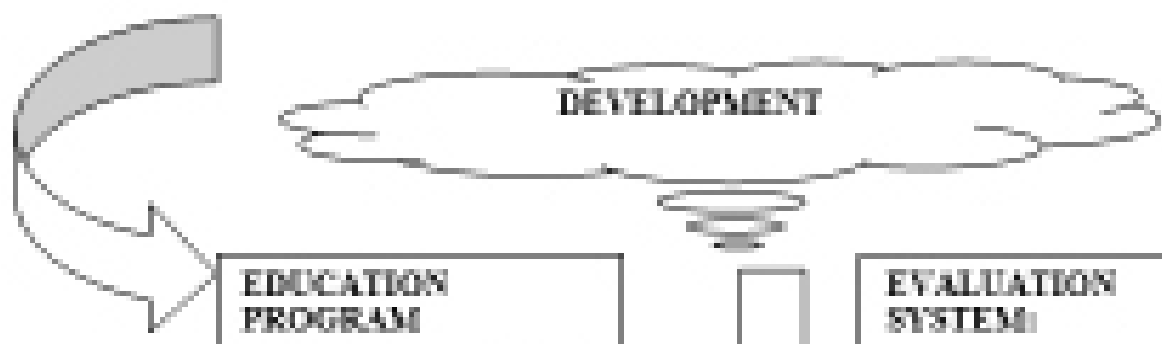

\section{EDLGATIAN
PRDThAM} DETERIVITIOF |

- Eluotions mou for peintrits

- Ehotinal mpru to batrur todar

- Etrothud propun tis mitit.

- Etrotinul propun tor th gredphis

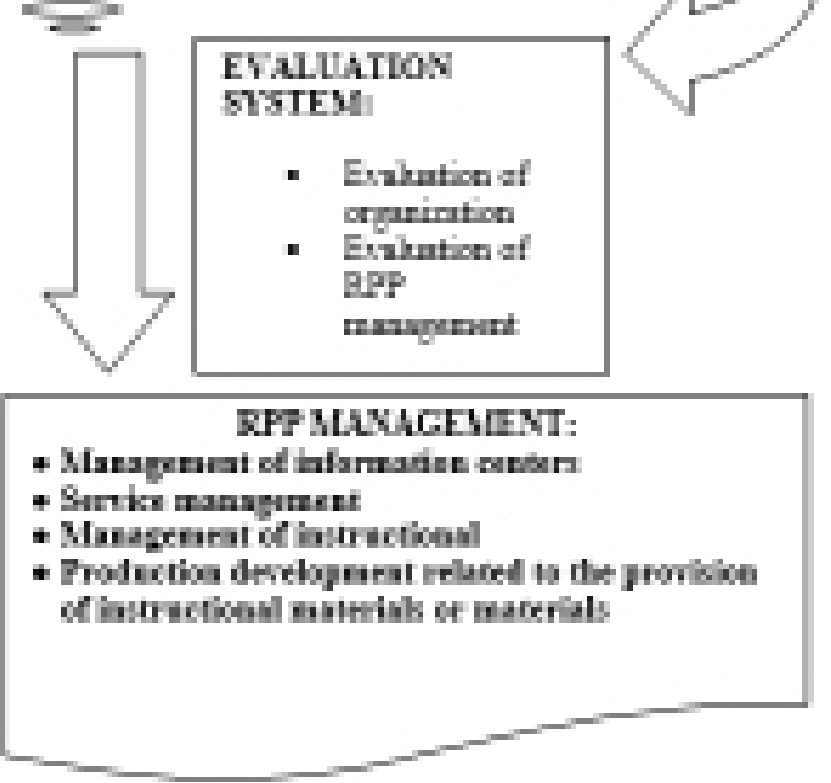

Diagram 1: The Development Models of Election Smart House as A Tool of Political Education Based on Local Wisdom

(1) educational programs for pre-voters; (2) educational programs for beginner voters; (3) educational programs for women; and (4) educational programs for the general public. Each program is compiled as needed. Therefore, the steps that must be taken are designing the learning system of each education program through: (1) assessing the need to determine learning objectives; (2) conduct instructional analysis; (3) analyzing learner characteristics; (4) writing learning objectives or special competencies; (5) developing learning strategies; (6) develop an instrument of assessment of learning outcomes; (7) develop and choose learning materials; (8) designing and carrying out 
evaluations; and (9) revising the learning program in an educational program (Dick and Carey, in Rafni and Suryanef. 2018).

These educational programs are important, especially for beginner voters because beginner voters are assumed to have distinctive political behavior. (Campbell \& Niemi, 2016) have conducted research through the National Assessment of Educational Progress (NAEP), which proves the importance of efforts to evaluate voter education programs for beginner voters. Likewise, Persson and (Persson, Lindgren, \& Oskarsson, 2016) who examined 30,000 students to find out the influence of the level of education on their political knowledge and understanding of democratic values. Next Heller (2013) interestingly conducted an election simulation project in Germany named $\mathrm{U}-18$ to attract German youth to socialize the election. Knowledge and understanding of democratic values through the RPP is essentially trying to continue in maintaining a democratic political culture both by the community and the government as the state administrator. Political learning through the use of political education service space in the RPP if optimized is believed to be able to shape the political awareness of the community.

The presence of RPP is one source of political learning for beginner voters to improve their knowledge and participate in democratic life, es pecially elections. Participation is a distinctive feature of political modernization, namely the activities carried out by citizens to be involved in the decisionmaking process with the aim of influencing the decision making carried out by the government.

On the other hand, the development of RPP requires management that can facilitate political education on an ongoing basis. The management of RPP rests on the following four things: (1) the management principles of information centers aimed at who, how, and what content is made; (2) the principle of service management, depends on the quality of activities and service personnel; (3) the principles of management of instructional development are highly dependent on the ability to make need assessment, choose learning resources, evaluate and develop instructional programs; and (4) production management principles related to the provision of materials and instructional objects.

The RPP development also depends on four principles. First, the principle of managing the information center in the RPP is illustrated through information services on the KPU's official web site or social media. Information is aimed at users, both from pre-voters, beginner voters, female voters, disabled voters, or the community in general. Second, about the principle of service management which is very dependent on the quality of activities and service personnel. The research findings indicate that there is no guide /facilitator in the RPP. The RPP will be effectively used if it involves many relevant parties such as (1) building a network with the Teacher of Civic Education (PPKn). PPKn teachers can use RPP as a source of political learning resources for students. Instead, the PPKn teacher can also be trained as a guide for RPP; (2) building cooperation with stakeholders through the publication of activities and assistance with RPP development. The research findings show that private sector assistance plays a major role in the development of RPP.

While the third, the principle of instructional development is very dependent on the ability to make a needs analysis to choose learning resources, evaluate and develop instructional programs. Furthermore, the fourth, production management principles related to the provision of instructional materials or materials. The research findings show that the lack of local content is used as material for socialization in the RPP.

Management of RPP is a factor that determines the growth of RPP as one of the sources of political learning resources. According to Mudhofir (Rafni and Suryanef, 2018) to develop a learning resource center must do three things: First, conducting studies related to needs regarding what is needed to develop learning resource centers both in terms of human resources and material resources. Second, how to build effective facilities and facilities in a learning resource so that they meet the requirements for learning. Third, how to develop learning programs that can be used to improve the quality of learning and able to achieve its objectives. At this stage things that have become a necessity are carried out, that is: (1) designing local wisdom-based political education activities for services in the RPP; and (2) designing operational standards for RPP activities, management structures and development services for instructional programs; (3) building and developing physical facilities; and (4) developing an education program on RPP. Therefore, as an initial step in 
developing RPP, operational standards for RPP activities are needed, management structures and development services for instructional programs or how to provide learning resources or materials. According to Romiszowski in Rafni and Suryanef (2018) the development of teaching materials as a learning resource is highly dependent on four aspects, that are: (1) academic aspects; (2) social aspects; (3) recreational aspects; and (4) aspects of the development of study programs. Meanwhile the steps for developing teaching materials include the following stages: (1) in developing teaching materials the main step that needs to be prepared is an inventory of the materials to be developed to achieve the objectives of writing the teaching materials; (2) explore the learning resource center to determine suitable materials for teaching materials (materials);(3) determine the need for an appropriate topic or issue with the fact that in the environment of learners; (4) choose the procedure of learning to do; and (5) further designing teaching materials in accordance with the achievement of learning objectives. Teaching materials designed with regard to local values should be the basis for presenting the material in the lesson plan.

The success of the implementation of political education in the RPP requires a clear evaluation system to determine the effectiveness of its implementation and at the same time achieving the objectives of the RPP as a tool of ongoing political education. The evaluation was carried out to the participants of the education program which included four stages, namely: (1) the reaction stage meant to focus on how the participants reacted to the implementation of the education program, whether they understood the presentation/ service provided in the lesson plan, and could respond to the material presented and respond;(2) the learning stage, which is related to the learning outcomes of the education program participants and how far they are able to learn the knowledge, attitudes, and skills learned in the education program; (3) the stage of behavior (behavior) that is measured is whether there has been a transfer of learning in the participants of the educational program and can immediately be applied; and (4) result (evaluation), which is an evaluation that aims to measure how much the educational program has benefited the program objectives.

The evaluation was also carried out in the management of RPP management. Whether the services provided regarding the principle of managing information services have met the expected standards. How big is the accessibility of the community in reaching information. The next question is whether the community is satisfied with the activities of political education presented by the guider/facilitator in charge of the RPP. Then the extent to which management is able to present instructional programs that are more interesting and interactive so as to create a deep impression on the learning process itself. This needs to be evaluated continuously so that it is sustainable in other words the presence of RPP as a means of political learning can benefit the community.

Learning together in lesson plans can increase the activeness of citizens to participate in politics. The characteristics of active citizens in question, among others, are aware of their political rights and obligations, have a high level of political participation. One effort to become an active citizen is learning through experience in public discussions or learning together with democracy activists such as non-governmental organizations (non-governmental organizations $=$ NGO's) (Ribeiro, 2012). At the stage of implementation and evaluation, it has not been implemented because this article is only the elaboration of three stages of the ADDIE model. The overall findings show that the model constructed is the first step to develop RPP as a source of political learning resources.

Moreover according to Westheimer dan Kahe (Rafni dan Suryanef, 2017) there are some aspects that determine the success of the process of political education or civic education, namely: (1) the existence of responsible citizens to carry out their rights and obligations as lawful, political literacy, and build solidarity; (2) the presence of citizens who have a participant culture, actively participate such as knowing strategies to achieve common goals and being able to build social integration; (3) the citizens have a critical capability in dealing with various problems together, critical in giving orientation and solutions for the benefit of the nation.

\section{Conclusions}

Political education is crucial for the formation of citizens who have political awareness, political personality, and political skills. One of the facilities that can be a vehicle for the realization of this is the Smart Elections House (RPP) which was specifically initiated by 
the KPU to increase the political participation of the community both in quantity and quality. It's just in this context, the KPU as an initiator must also make a breakthrough and creativity so that the RPP does not lose the intrinsic meaning of the purpose of its presence, especially in relation to democratic life and as a tool of political education facility for society. These breakthroughs and creativity can take the form of adopting local culture to make political education more "down to earth" and in demand by the local community. It takes the seriousness and high commitment from both the KPU and the government to make the RPP function optimally in carrying out the mission of sustainable political education, especially for the younger generation. Not only in their position as future leaders but also as a potential segmentation of voters in elections.

RPP is a potential learning resource center as a tool of political education facility for society. Political education facility for a society based on local wisdom through RPP can be used as an alternative means of integrated political learning. And it can increase citizens' political flexibility while increasing community participation in the life of democracy. The political education activities contained in the RPP need to be developed by standardizing services and facilities as well as more effective management.

\section{References}

Ahmed, I. (2016). "Building Resilience of Urban Slums in Dhaka, Bangladesh. Procedia - Social and Behavioral Sciences." 218, 202-213. https://doi.org/10.1016/j. sbspro.2016.04.023

Campbell, D. E., \& Niemi, R. G. (2016). "Testing civics: State-level civic education requirements and political knowledge." American Political Science Review. https:// doi.org/10.1017/S0003055416000368

Dinesen, P. T., Dawes, C. T., Johannesson, M., Klemmensen, R., Magnusson, P., Nørgaard, A. S., Oskarsson, S. (2016). "Estimating the Impact of Education on Political Participation: Evidence from Monozygotic Twins in the United States, Denmark and Sweden." Political Behavior. https://doi.org/10.1007/s11109-0159328-2

Fowler, A., \& Margolis, M. (2014). "The political consequences of uninformed voters." Electoral Studies, 34, 100-110. https:// doi.org/10.1016/j.electstud.2013.09.009

Harrison Iii, H. L., \& Hummell, L. J. (2010).
"Incorporating Animation Concepts and Principles in STEM Education." Technology Teacher.

Heller, Lydia. (2013). "Pendidikan Politik Lewat Pemilu Untuk Remaja", http:// www.dw.com/id/pendidikan-politik-lewatpemilu-untuk remaja. Diakses tanggal 20 Oktober 2018.

Komisi Pemilihan Umum (KPU) Republik Indonesia. (2016). Bunga Rampai Rumah Pintar Pemilu 2015 - 2016. Jakarta : KPU RI.

Morrison, G. R., Ross, S. J., Morrison, J. R., \& Kalman, H. K. (2019). Designing effective instruction. Wiley.

Pacho, T. (2014). "Necessity Of Political Education." International Journal of Innovative Research and Studies, 3(11), 10-17. Retrieved from http://www.ijirs. $\mathrm{com} / \mathrm{vol} 3$ issue-11/2.pdf

Persson, M., Lindgren, K. O., \& Oskarsson, S. (2016). How does education affect adolescents' political development? Economics of Education Review, 53, 182-193. https://doi.org/10.1016/j. econedurev.2016.03.015

Rafni, Al \& Suryanef. (2016). "Pengembangan Model Pelatihan Relawan Demokrasi Sebagai Fasilitator Pendidikan Politik Berbasis Komunitas (Studi Terhadap Relawan Demokrasi Pemilu 2014 di Kota Padang)." LPPM-UNP

Rafni, Al \& Suryanef. (2017). "Roles of Democratic Volunteers in Developing Political Literacy" dalam MIMBAR : Jurnal Sosial dan Pembangunan, Volume 33, No.1 (June2017) pp. 1-218.

Rafni, Al \& Suryanef. (2018). "Model Pengembangan Rumah Pintar Pemilu Sebagai Sarana Pendidikan Politik Berkelanjutan Berbasis Kearifan Lokal (Studi Pada KPU Kota Bukittinggi dan KPU Provinsi Sumatera Barat)." LPPM-UNP

Ribeiro, A. B., Rodrigues, M., Caetano, A., Pais, S., \& Menezes, I. (2012). "Promoting Active Citizens? The Critical Vision of NGOs over Citizenship Education as an Educational Priority across Europe." International Journal of Progressive Education, 8(3).

Sánchez-Villar, J., Bigné, E., \& Aldás-Manzano, J. (2017). "Blog influence and political activism: An emerging and integrative model." Spanish Journal of Marketing - ESIC. https://doi.org/10.1016/j. sjme.2017.02.002

Setiawaty, D. (2014). "Mendorong Partisipasi Pemilih Muda Melalui Pendidikan Politik Yang Programatik." Islamic Review: Jurnal Riset Dan Kajian Keislaman, III(1), 117-146.

Wirdanengsih. (2018). Kearifan Lokal Minangkabau. Yogyakarta : Deepublish 